\title{
Mediation And Moderation Models on The Effect of Empowering Leadership and Professionalism Toward Lecturer Performance
}

\author{
Khusnul FIKRI ${ }^{1}$, Haryadi $^{2^{*}}$, Edward $^{3}$, Rike SETIAWATI ${ }^{4}$ \\ ${ }^{1}$ Lecturer in Economics and Business, University of Muhammadiyah Riau; \\ Student in Economics and Business, University of Jambi; E-mail: khusnulfikri@umri.ac.id; \\ ${ }^{2}$ Professor in Economics and Business, University of Jambi; E-mail: haryadi.fe@unja.ac.id; \\ ${ }^{3}$ Lecturers in Economics and Business, University of Jambi; E-mail: edwardlempo@gmail.com; \\ ${ }^{4}$ Lecturers in Economics and Business, University of Jambi: E-mail: rike_setiawati@unja.ac.id; \\ ${ }^{*}$ Corresponding Author
}

\author{
Received: 12.07.2021 Accepted: 02.09.2021 Published: 26.10.2021 DOI: $\underline{10.47750 / Q A S / 22.184 .25}$
}

\begin{abstract}
This study aims to develop a conceptual model of the influence of leadership empowerment and professionalism on lecturer performance using work motivation as a mediating and moderating variable, self-efficacy, and locus of control as a moderating variable. Sampling used a cluster random sampling technique on 317 respondents from private university lecturers from Jambi and Riau Provinces which was carried out by sending a questionnaire via Google Form to the institutional email and then forwarded to the lecturer as a respondent. Data analysis was performed using Partial Least Square-Structural Equation Modeling with WarpPLS 7.0 software. The study's findings include that the fit and quality index models have validated their value; empowering leadership has a positive and significant effect on lecturer performance; professionalism has a positive but not significant effect on lecturer performance; work motivation has a positive and significant effect on lecturer performance; work motivation partially mediates the effect of empowering leadership on lecturer performance; work motivation fully mediates the effect of professionalism on lecturer performance; motivation weakens the effect of empowering leadership on lecturer performance but not significantly; work motivation can significantly strengthen the influence of professionalism on lecturer performance; self-efficacy weakens the effect of empowering leadership on lecturer performance but not significantly; locus of control can strengthen the influence of professionalism on lecturer performance but not significantly.
\end{abstract}

Keywords: Empowering Leadership; Professionalism; Lecturer Performances

\section{Introduction}

Previous empirical studies have shown that empowering leadership affects employee performance (Ahearne et al., 2005; Ahmed et al., 2017; Dash \& Vohra, 2019; Hasbullah \& Moeins, 2016; Tung \& Chang, 2011; Zhang \& Gheibi, 2015), empirical studies others leadership does not affect employee performance (Nurlaela et al., 2017; Tone, 2015). Professionalism affects employee performance (Jumriati et al., 2018; Kusuma et al., 2018; Pujiastuti et al., 2017). However, other empirical studies show that professionalism does not affect employee performance (Putra \& Ariyanto, 2012; Trisnaningsih et al., 2012). Furthermore, while some empirical studies reveal that work motivation has an impact on employee performance (Andriani et al., 2018; Bastari et al., 2020; Gachengo \& Wekesa, 2017; Pujiastuti et al., 2017; Sandrin et al., 2019; Sardjana et al., 2018; Wibisono et al., 2018; Oprescu \& Militaru, 2012; Cojocariu, 2011), others show that work motivation does not affect performance (Hartinah et al., 2020; Tone et al., 2015). Based on the results of previous studies, the authors conclude that previous studies' findings are inconsistent and that there is a research gap examine the influence of variables such as empowering leadership, professionalism and work motivation on performance, necessitating additional research. Referring to previous research on the concept of performance and empirical studies conducted by previous researchers, this study empirically examines the concept of employee performance. The research object is the private colleges in the provinces of Jambi and Riau, and the population is the lecturers. These variables are chosen based on earlier research that revealed a research gap. In one research paradigm, the researcher proposes a solution by combining mediation and moderation. There may be other exclusive variables and may fill this research gap. This study utilizes mediating and moderating mechanisms of work motivation variables and moderating mechanisms of self-efficacy and locus of control on the influence of empowering leadership with a structural equation modeling approach. The mediating and moderating variables intend to fill the gap between endogenous and exogenous variables in this study. 


\section{Literature Review}

\section{The effect of empowering leadership on lecturer performance.}

Amundsen \& Martinsen (2014) stated that the role of employee empowerment lies in making employees independent and able to lead themselves. Self-leadership includes the skills and tactics used by individuals to prope themselves towards achieving higher levels of effectiveness and performance (Ahmed et al., 2017). Vecchio et al. (2010) found that leaders who share power with subordinates contribute to job satisfaction improvement and performance among their subordinates. Empowering leadership indicators: Meaningfulness of work; Fostering participation in decisionmaking; Expressing confidence in high performance; Providing autonomy from bureaucratic constraints; Appreciating employees; Developing employees; Building community; Delegation of power (Ahearne et al., 2005; Jones, 2013). Lecturer performance indicators: Education and teaching; Research; Community service (Government Regulation Number 37 of 2009; Law Number 12 of 2012).

$\mathrm{H} 1$. It assumed empowering leadership has a significant effect on lecturer performance.

\section{The effect of professionalism on lecturer performance.}

Vroom (2006) states that a person's performance is influence by professionalism. The expected performance is difficult to achieve if the work demands imposed on employees do not meet their abilities. Lecturers are required to provide educational guidance to their students and must have particular professional skills (Hamalik, 2002). Indicators of professionalism: planning, implementing the learning process, assessing and evaluating learning outcomes; Increasing and developing academic qualifications and competencies on an ongoing basis in line with the development of science, technology, and art; acting objectively and non-discriminatory based on considerations of gender, religion, ethnicity, race, certain physical conditions, or the socio-economic background of students in learning; upholding laws and regulations, laws, and codes of ethics, as well as religious and ethical values; maintaining and fostering national unity and integrity dedication to the profession; relationships with the fellow profession; mental attitude; teaching skills; interpersonal skills (Abeng, 2002; Mawardi, 2011; Morrow \& Goetz, 1988; Permanasari et al., 2014; Law Number 14 of 2005).

$\mathrm{H} 2$. It assumed professionalism has a significant effect on Lecturer Performance.

\section{The effect of work motivation on lecturer performance.}

According to Robbins (2008), performance is a result of the relationship between ability and motivation. If an individual's motivation does not match what is required, his performance will suffer. According to Mathis \& Jackson (2012), individual support received from the organization determines the firm's expected performance. The interaction between motivation and situational factors, according to McClelland (1987), is what enables motivation to do action to emerge. Motivation is one of the factors that influence an organization's human resources to perform effectively. Human resources are driven to increase performance and do their best for the organization as a result of the motivation provided by the organization. Work motivation indicators include the desire to succeed; to attain in terms of a set of standards; to make an effort to succeed (McClelland, 1987).
H3. It assumed work motivation has a significant effect on lecturer performance.

\section{Work motivation mediates the influence of empowering leadership on lecturer performance}

The motivation variable can be a mediating variable between leadership empowerment variables on lecturer performance through a contingency approach. According to Suliyanto (2018), the mediation approach is used to address the research gap by incorporating mediation variables. Tone et al. (2015) found that whereas leadership has a negative and significant effect on work motivation, it has a positive and insignificant effect on lecturer performance. As per Nurlaela et al. (2017), leadership has no significant influence on lecturer performance. However, according to Guterresa et al. (2020), if a leader can combine the effective leadership style in the organization, employees will feel empowered and will able to carry out their duties more efficiently and effectively. Spurring their creativity and innovative abilities, which will lead to improved performance. To improve employee performance, it is critical to motivating employees' work from the applied leadership style. The use of non-coercive influence to create a group or organizational goals encourage behavior that assists in goal achievement and defines the group or organization's culture are examples of leadership (Griffin, 2004).

$\mathrm{H} 4$. It assumed work motivation mediates the influence of empowering leadership on lecturer performance.

\section{Work motivation mediates the influence of} professionalism on lecturer performance

Motivation is a variable that acts as a mediator between the independent and dependent variables in an indirect relationship. Several studies evaluating the direct influence of the independent variable on the dependent variable show some inconsistencies. According to the findings of Trisnaningsih et al. (2012), there is no significant effect between professional commitment and lecturer performance variables. Robbins (2008) explains a person's willingness to work hard to achieve goals and influence his ability or intensity in meeting his needs. Bangsawan et al. (2020), citing Carrel and Dittrich, underline the necessity of rewarding and recognizing employees based on their achievements by giving rewards and recognition from the organization. Employees will be encouraged to use their abilities to accomplish work and increase work efforts, allowing them to advance their careers in the workplace.

H5. Work motivation is assumed able to mediate the influence of lecturer professionalism on lecturer performance.

\section{Work motivation strengthens the influence between empowering leadership and lecturer performance.}

Motivation is a core leadership competency, according to Latham (2007), and it is a function of the expectation of success in a given situation and the value placed on the outcome. Motivation is an essential consideration since effective performance often demands high ability and motivation (Bagraim \& Werner, 2003). As per Bass (1991), some leaders recognize the importance of their leadership influence on their employees' performance and satisfaction.

H6. Work motivation is assumed to strengthen the influence of Empowering Leadership and Lecturer Performance. 


\section{Work motivation strengthens the influence between lecturer professionalism and lecturer performance.}

Robbins (2008) revealed that employee performance is a function of the interaction between ability and motivation; performance $=f(\mathrm{AxM})$. If anything is insufficient, that performance will be negatively affected. The performance achievement of a person who is motivated by someone who does not have both internal and external motivations must be different. Motivation affects a person's behaviors and work processes, assists lecturers in improving their abilities (Zee et al. (2018). Performance refers to the degree of success in completing activities and the capacity to accomplish defined objectives. It is a result of motivation. On the other hand, if the desired goal is met, performance and success will follow (Shah et al., 2017). According to Spencer \& Spencer (1993), competence is defined as a person's underlying characteristics related to the effectiveness of individual performance at work and standard characteristics of individuals who have causal relationships or causal references, are effective, primary, or preferable performers at work.

H7. It assumed the work motivation strengthens the influence between lecturer professionalism and lecturer performance.

\section{Self-efficacy strengthens the influence between empowering leadership with lecturer performance.}

Dennerlein decided to look into the general self-confidence of the employees in their job role, referred to as work-role self- efficacy, which defined as a belief in overall competence to succeed in performance requirements across various achievement situations in work role as a moderator of leadership empowerment) for a variety of reasons. First, people's motivation is influenced by their self-efficacy beliefs, as seen by goal selection, goal or task persistence, goal revision, and goal struggle behavior (Bandura, 1997). As a result, work-role self-efficacy can indicate how "prepared" people feel about leadership empowerment and the extent to which they can still benefit from it (for example, in terms of developing themselves). Second, Dennerlein looked at general (vs. specialize) self-efficacy, since he studied at two different performance outcomes (creativity and role performance), could be linked to the different work activities within its area.

H8. It assumed the self-efficacy strengthens the influence between Empowering Leadership and Lecturer Performance.

\section{Locus of control strengthens the influence between lecturer professionalism and lecturer performance.}

According to Robbins (2008)Robbins (2008), locus of control is the degree to which individuals believe they are in charge of their destiny. Internal factors are the factors that they possess to control their lives. External factors are factors that individuals believe their lives determine by forces beyond their control, such as luck and opportunity. Locus of control is a personality variable and defined as an individual's belief in control destiny, as per Kreitner \& Kinicki (2014).

H9. It assumed locus of control strengthens lecturer professionalism and performance.

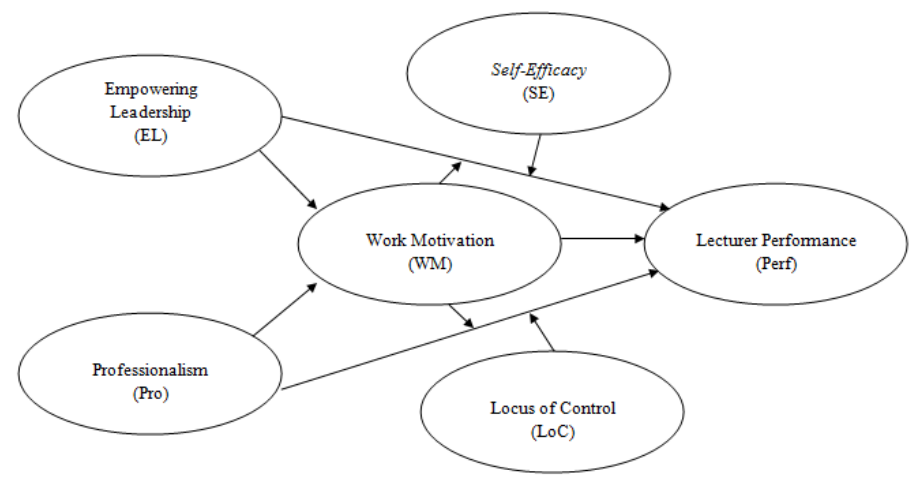

Fig. 1: Conceptual Framework

\section{Methods}

This study falls under the category of descriptive research. Descriptive research is a type of study that seeks to examine and evaluate objects based on their characteristics. Since the research objectives and hypotheses in this study can be verified, descriptive research was used in this study, defined as a study that uses a quantitative (positivist) approach and a questionnaire as the primary data instrument to explain the causal relationship between variables. The data in this study divided into two categories: primary and supporting data. The primary data is collected by sending questionnaires via Google Form to institutional emails and then forwarding them to lecturers as respondents, a total of 317 participants. The supporting data is quantitative data derived from performance reports, web pages, and other sources. Sampling performed using the cluster random sampling technique. The author utilizes a data analysis technique named Partial Least SquareStructural Equation Modeling with WarpPLS 7.0 software to answer the hypothesis. 


\section{GENERAL MANAGEMENT}

\section{Result \\ Measurement Model \\ Convergent Validity}

\begin{tabular}{|c|c|c|c|c|c|c|}
\hline EL & Pro & WM & S-E & LoC & Perf & P Value \\
\hline 0.678 & 0.769 & 0.781 & 0.615 & 0.787 & 0.759 & \multirow{13}{*}{$<0.001$} \\
\hline 0.773 & 0.811 & 0.773 & 0.785 & 0.906 & 0.736 & \\
\hline 0.764 & 0.791 & 0.764 & 0.641 & 0.844 & 0.520 & \\
\hline 0.700 & 0.736 & 0.696 & 0.704 & 0.854 & 0.602 & \\
\hline 0.860 & 0.809 & 0.818 & 0.807 & 0.838 & 0.612 & \\
\hline 0.650 & 0.831 & 0.728 & 0.805 & 0.855 & 0.659 & \\
\hline 0.697 & 0.614 & & & 0.859 & 0.630 & \\
\hline 0.623 & 0.625 & & & & 0.558 & \\
\hline 0.698 & & & & & 0.599 & \\
\hline 0.782 & & & & & 0.767 & \\
\hline 0.733 & & & & & 0.613 & \\
\hline 0.794 & & & & & 0.551 & \\
\hline 0.699 & & & & & 0.695 & \\
\hline
\end{tabular}

Table 1: Output Combined Loadings and Cross Loadings Source: WarpPLS 7.0

Table 1 shows that there are no indications of the loading of less than 0.40 . Hence the indicators listed in the table can be employed. Furthermore, the Output value of AVE and
Composite Reliability is seen as prove and convince. The results of the AVE value and composite reliability on the latent variable output coefficients are as below.

\begin{tabular}{|l|l|l|l|l|l|l|}
\hline & EL & Pro & \multicolumn{1}{|c|}{ WM } & S-E & LoC & Perf \\
\hline R-Square & & & 0.283 & & & 0.440 \\
\hline Adj R-Square & & & 0.278 & & & 0.428 \\
\hline Composite Reliability & 0.936 & 0.912 & 0.892 & 0.871 & 0.948 & 0.900 \\
\hline Cronbach's alpha & 0.926 & 0.888 & 0.854 & 0.822 & 0.935 & 0.879 \\
\hline Avg. Var. Extrac & 0.532 & 0.566 & 0.579 & 0.533 & 0.722 & 0.414 \\
\hline Full collin. VIF & 1.438 & 1.319 & 1.689 & 1.154 & 1.415 & 1.630 \\
\hline Q-Square & & & 0.273 & & & 0.388 \\
\hline
\end{tabular}

Table 2: Output Latent Variable Coefficients Source: WarpPLS 7.0

Table 2 reveals that the AVE value of the variables empowering leadership, professionalism, work motivation, selfefficacy, and locus of control is higher than 0.50, and composite reliability is more than 0.70 , whereas the performance variable is 0.414 , which is less than 0.50 . The recommended minimum AVE value is 0.5 , but an AVE value of less than 0.5 is acceptable, as stated by Fornell \& Larcker (1981) that AVE can be accepted if the AVE value is 0.4 , because if the AVE is less than 0.5 , but the composite reliability is higher than 0.6 , the convergent validity of the construct is still adequate, such as research done by (Lam, 2012; Pervan et al., 2018) wherein their research with AVE below 0.5

Furthermore, the composite reliability results in Table 3 reveal that all variables satisfied the requirement of being higher than 0.70 . The overall collinearity VIF score in Table 2 is less than 3.3, indicating the model is free of vertical, lateral, and bias of collinearity issues. The convergent validity requirement has been fulfilled.

\section{Discriminant Validity}

\begin{tabular}{|c|c|c|c|c|c|c|}
\hline & EL & Pro & WM & S-E & LoC & Perf \\
\hline EL & $(0.730)$ & -0.006 & 0.078 & 0.088 & -0.012 & 0.517 \\
\hline Pro & -0.006 & $(0.752)$ & 0.462 & 0.155 & 0.330 & 0.136 \\
\hline WM & 0.078 & 0.462 & $(0.761)$ & 0.212 & 0.478 & 0.280 \\
\hline ES-E & 0.088 & 0.155 & 0.212 & $(0.730)$ & 0.086 & 0.256 \\
\hline LoC & -0.012 & 0.330 & 0.478 & 0.086 & $(0.849)$ & 0.147 \\
\hline Perf & 0.517 & 0.136 & 0.280 & 0.256 & 0.147 & $(0.643)$ \\
\hline
\end{tabular}

Table 3: AVE Square Root

Source: WarpPLS 7.0 


\section{GENERAL MANAGEMENT}

Table 3 presents that the square root value of AVE obtained by all variables is greater than the correlation between latent variables in the same column and row, implying that all variables exhibit discriminant validity.

\section{Reliability Test}

The composite reliability and Cronbach's alpha for each variable are higher than 0.70 , as shown in Table 2. It demonstrates that all variables are reliable or can be relied on as variables. It can conclude that all construct variables meet the requirements for reliability and can further examine.

\section{Structural Model Testing \\ Coefficient of Determination}

The R-squared value of the work motivation variable is 0.283 , while the $R$-squared value of the performance variable is 0.440 , based on the data in Table 2. The empowering leadership and professionalism variables can explain 28.3 percent of the work motivation variable. The remaining 71.7 percent is explained by other variables not discussed in this study or other factors outside the model. The variables empowering leadership, professionalism, work motivation, selfefficacy, and locus of control are explained by 44 percent of the performance variable. The remaining 56 percent explained by other variables not mentioned in this study or factors outside the model.

\section{Model Fit and Quality Indices}

\begin{tabular}{|c|c|c|c|}
\hline $\begin{array}{l}\text { Model Fit and } \\
\text { Quality Indices }\end{array}$ & Criteria & Test results & Exp \\
\hline APC & \multirow{3}{*}{ Accepted if $p<0,05$} & $0.194, \mathrm{P}<0.001$ & \multirow{9}{*}{ Accepted } \\
\hline ARS & & $0.362, \mathrm{P}<0.001$ & \\
\hline AARS & & $0.353, P<0.001$ & \\
\hline AVIF & \multirow{2}{*}{ Accepted if $\leq 5$} & 1.397 , acceptable if $<=5$, ideally $<=3.3$ & \\
\hline AFVIF & & 1.413, acceptable if $<=5$, ideally $<=3.3$ & \\
\hline SPR & \multirow{4}{*}{ Accepetd if $\geq 0.7$; ideally $=1$} & \multirow[t]{3}{*}{ 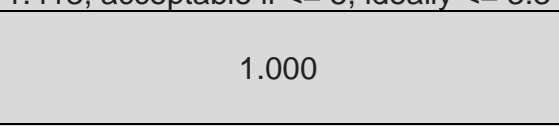 } & \\
\hline RSCR & & & \\
\hline SSR & & & \\
\hline NLBCDR & & 0.778 & \\
\hline GoF & $\begin{array}{c}\text { Small } \geq 0.1 ; \text { Moderate } \\
0.36\end{array}$ & 0.515 & Large \\
\hline
\end{tabular}

Table 4: Value Model Fit and Quality Indices

Source: WarpPLS 7.0

The standard model fit and quality indices in this model have fulfilled what was required, as shown in Table 4. It shows that the model in this study has a good Goodness of Fit, and there is no multicollinearity problem between indicators and between exogenous variables.

\section{Predictive Relevance}

The Q-squared value is greater than zero, as shown by the estimation findings in Table 3 , with work motivation of 0.273 and performance of 0.388 . As a result, this research model considers having good predictive validity.

\section{Effect Size}

\begin{tabular}{|c|r|r|r|l|}
\hline & EL & \multicolumn{1}{c|}{ Pro } & WM & Perf \\
\hline EL & & & & \\
\hline Pro & & & & \\
\hline WM & 0.012 & 0.271 & & \\
\hline Perf & 0.286 & 0.000 & 0.107 & \\
\hline
\end{tabular}

Table 5: Effect Size for Path Coefficients

Source: WarpPLS 7.0

Table 5 reveals that empowering leadership has a 0.012 influence on work motivation, professionalism has a 0.107 influence on performance, and work motivation has a 0.107 influence on performance. Meanwhile, those included in the medium category are professionalism on work motivation, with a value of 0.271 , and empowering leadership on performance, with a value of 0.286 . 


\section{GENERAL MANAGEMENT}

\section{Hypothesis Test}

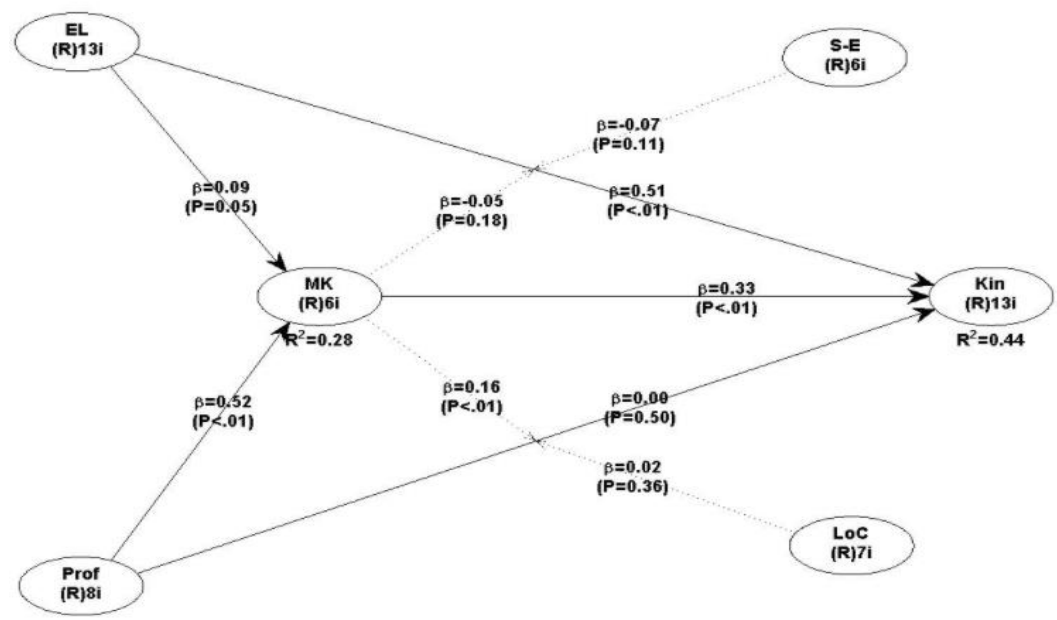

Source: WarpPLS 7.0

Fig. 2: Indirect Effect Research Model Testing

\section{Direct Testing}

\begin{tabular}{|c|c|c|c|}
\hline Hypothesis & Path Coefficient & P-value & Explanation \\
\hline EL $\rightarrow$ Perf & 0.51 & $\mathrm{P}<0.01$ & Positive and Significant \\
\hline Pro $\rightarrow$ Perf & 0.00 & $\mathrm{P}=0,50$ & Positive and Insignificant \\
\hline WM $\rightarrow$ Perf & 0.33 & $\mathrm{P}<0.01$ & Positive and Significant \\
\hline
\end{tabular}

Table 6: Path Coefficient Estimation Results

Source: WarpPLS 7.0 data processing

\section{Hypothesis 1.}

Based on the path coefficient value of 0.51 and the $P$-value of $\mathrm{P}<0.01<0.05$, Ho is rejected and $\mathrm{Ha}$ is accepted. It can be concluded that empowering leadership has a positive and significant effect on lecturer performance.

\section{Hypothesis 2.}

Based on the path coefficient value of 0.00 and the P-value of $\mathrm{P}=0.50$, then $\mathrm{Ho}$ is accepted and $\mathrm{Ha}$ is rejected. It can be concluded that professionalism has a positive but insignificant effect on lecturer performance.

\section{Hypothesis 3.}

Based on the path coefficient value of 0.33 and the $P$-value of $\mathrm{P}<0.01<0.05$, $\mathrm{Ho}$ is rejected and $\mathrm{Ha}$ is accepted. It can be concluded that work motivation has a positive and significant effect on lecturer performance.

\section{Mediation Effect Test}

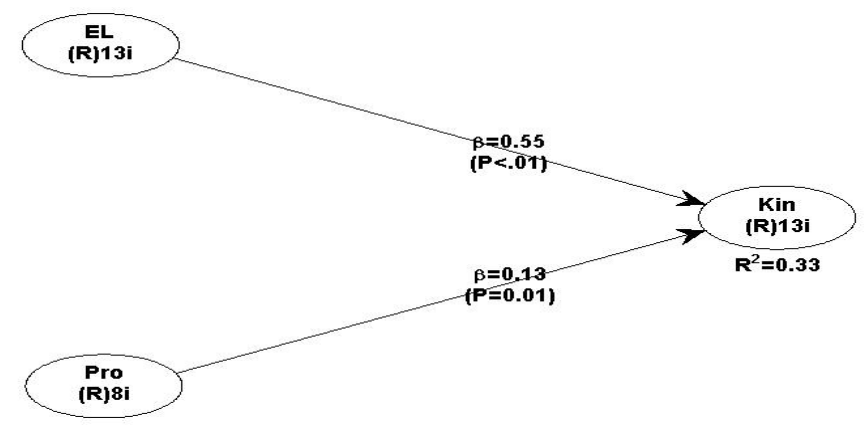

Source: WarpPLS 7.0

Fig. 3. Testing the Direct Effect Research Model 


\begin{tabular}{|c|c|c|c|c|}
\hline \multirow{2}{*}{ Hypothesis } & \multicolumn{2}{|c|}{ Direct effect } & \multicolumn{2}{c|}{ Indirect effect } \\
\cline { 2 - 5 } & Path Coefficient & P-value & Path Coefficient & P-value \\
\hline EL $\rightarrow$ Perf & 0.55 & $\mathrm{P}<0.01$ & 0.51 & $\mathrm{P}<0.01$ \\
\hline Pro $\rightarrow$ Perf & 0.13 & $\mathrm{P}=0.01$ & 0.00 & $\mathrm{P}=0.50$ \\
\hline
\end{tabular}

Table 7: Recapitulation of Direct Effect and Indirect Effect Estimation Results Source: WarpPLS 7.0 data processing

According to Hair (2017) and Kock (2011), as quoted by Sholihin \& Ratmono (2021), the following factors should be considered when making mediation decisions: 1) Ho is accepted and $\mathrm{Ha}$ is rejected if the path coefficient from direct to indirect effect does not change and remains substantial. 2) Partial mediation occurs when the path coefficient from direct effect to indirect effect decreases but remains significant. 3) Full mediation is used when the route coefficient from direct to indirect influence decreases but becomes insignificant.

\section{Hypothesis 4.}

The path coefficient of the direct effect, which was formerly
0.55, has become 0.51 , although the $P$-value remains significant. Work motivation partially mediates (partial mediation) the effect of empowering leadership on lecturer performance. As a result, $\mathrm{Ho}$ is rejected and $\mathrm{Ha}$ is accepted.

\section{Hypothesis 5.}

The path coefficient of the direct effect to the indirect effect, which was 0.13 , decreases to 0.00 , and the $P$-value is no longer significant. Work motivation fully mediates (full mediation) the effect of professionalism on lecturer performance. As a result, $\mathrm{Ho}$ is rejected and $\mathrm{Ha}$ is accepted.

\section{Moderation Effect Test}

\begin{tabular}{|c|c|c|c|}
\hline Hypothesis & Path Coefficient & P-value & Explanation \\
\hline$E L^{*} \mathrm{WM} \rightarrow$ Perf & -0.05 & $\mathrm{P}=0.18$ & Negative (weaken) and Insignificant Moderation \\
\hline Pro*WM $\rightarrow$ Perf & 0.16 & $P<0.01$ & $\begin{array}{c}\text { Positive (able to strengthen) and Significant } \\
\text { Moderation }\end{array}$ \\
\hline$E L^{*} S-E \rightarrow P e r f$ & -0.07 & $\mathrm{P}=0.11$ & Negative (weaken) and Insignificant Moderation \\
\hline Pro*LoC $\rightarrow$ Perf & 0.02 & $P=0.36$ & $\begin{array}{c}\text { Positive (able to strengthen) and Insignificant } \\
\text { moderation }\end{array}$ \\
\hline
\end{tabular}

Table 8: Estimation Results of Indirect Effect Moderation Source: WarpPLS 7.0

\section{Hypothesis 6.}

The test result shows the Path Coefficient of -0.05 with a $P$ value of $0.18 \geq 0.05$, indicating that motivation decreases, but not significantly, the influence of empowering leadership on lecturer performance, Ha rejected and Ho accepted.

\section{Hypothesis 7.}

The test result shows the Path Coefficient value of 0.16 with a $P$-value $<0.01 \leq 0.05$, indicating that work motivation significantly strengthens the influence of professionalism on lecturer performance, Ho rejected and Ha accepted.

\section{Hypothesis 8.}

The Path Coefficient value of -0.07 with a P-value of 0.11 $\geq 0.05$ indicates that self-efficacy weakens, but not significantly, the influence of empowering leadership on lecturer performance, as Ha rejected and Ho accepted.

\section{Hypothesis 9.}

The Path Coefficient value of 0.02 with a P-value of $<0.36$ $\geq 0.05$ indicates that locus of control strengthens the influence of professionalism on lecturer performance, though not significantly, Ho rejected and $\mathrm{Ha}$ accepted.

Other findings include that empowering leadership has a positive and significant effect on work motivation, so does professionalism.

\section{Discussion}

The influence of empowering leadership on lecturer performance.

Empowering leadership has a positive and significant effect on the performance of permanent lecturers. The results of this study support the theory put forward by Amundsen and Martinsen $(2014,2015)$ that the role of employee empowerment lies in making employees independent and able to lead themselves. Self-leadership includes the skills and tactics used by individuals to propel themselves towards achieving higher levels of effectiveness and performance (Ahmed et al., 2017). Vecchio et al. (2010) found that leaders who share power with subordinates, in general, contribute to higher levels of job satisfaction and performance among these subordinates. Jones (2013) mentioned empowering leadership defined as a leader's ability to understand motivation and behavior. Showing a leader has an attitude of interest and care for his employees, can communicate effectively, and can inspire his employees. The results of this study are in line with the results of research conducted by (Ahearne et al., 2005; Dash \& Vohra, 2019; Fitria et al., 2017; Hasbullah \& Moeins, 2016; Sarboini et al., 2018; Tung \& Chang, 2011; Zhang \& Gheibi, 2015), which resulted in research that empowerment leadership affects performance. The results of this study refute the results of research conducted by Tone et al. (2015) and Nurlaela et al. (2017), revealed there was no significant influence between leadership on performance. 


\section{The influence of lecturer professionalism on lecturer performance.}

Professionalism has a positive and insignificant effect on the performance of permanent lecturers. It means higher professionalism of the lecturer; the lecturer's performance will increase but not significantly with a 95\% confidence level (error $5 \%$ ). The results of this study are in line with the research of Ramadika et al. (2014) concluded professionalism has no significant effect on auditor performance. A study conducted by Putra \& Ariyanto (2012) reveals an insignificant effect of professionalism on performance. The results of this study are not in line with the results of research conducted by Trivena \& Harisno (2014); Hasbullah \& Moeins (2016); Basri et al. (2019) concluded that professionalism has a positive and significant effect on performance.

\section{The effect of work motivation on lecturer performance.}

Work motivation has a positive and significant effect on the performance of permanent lecturers. The results of this study support the theory proposed by Robbins (2008) reveals that performance is a function of the interaction between ability and motivation. If an individual ability and motivation are not following what is needed, it will harm his performance. Mathis \& Jackson (2012) stated that the performance sought by the company from a person depends on the ability, motivation, and individual support received. The results of this study are in line with the results of research conducted by Pujiastuti et al. (2017), Wibisono et al. (2018), Sardjana et al. (2018), Sandrin et al. (2019), suggest that motivation has a significant effect on performance. The results of this study refute the results of Tone et al. (2015) found that work motivation on lecturer performance is evidenced by a negative direction, meaning that high motivation tends to reduce lecturer performance.

\section{Work motivation can mediate the influence of empowering leadership on lecturer performance.}

Work motivation partially mediates the influence of empowering leadership on performance. Work motivation mediates some of the effects of empowering leadership on lecturer performance. It means that the higher the empowering leadership of the head of the study program on the performance of the lecturers, the higher the performance level of the lecturers performed through work motivation. This form of partial mediation shows that work motivation is not the only mediating influence of empowering leadership on lecturer performance, which means there are other mediating factors. Research results Consistent research with Tung \& Chang (2011) found that two indirect effects add to the direct effect of leadership empowerment on team performance, knowledge sharing mechanisms, and team cohesion. In other words, knowledge sharing and team cohesion, respectively, mediate the relationship between leadership empowerment and performance. Similarly, the results of research by Diputra et al. (2018) and Sappe et al. (2016) revealed motivation mediates positively and significantly the influence of leadership on performance.

\section{Work motivation can mediate the influence of lecturer professionalism on lecturer performance.}

The full mediation shows that work motivation is the only mediating influence of professionalism on lecturer performance by means that there are no other mediating factors. The results of this study support the opinion put forward by Robbins (2008), which explains a process of a person's willingness to achieve goals, conditioned by a person's ability or intensity in meeting his needs. Similarly, Carrel and Dittrich (Bangsawan et al., 2020) emphasize the importance of awarding and recognizing employees according to their achievements. By providing rewards and recognition from the organization, employees will be encouraged to perform their abilities to work and increase work efforts, enabling them to advance their careers in the workplace. The study outcomes also support the research results of Pujiastuti et al. (2017) concluded that professiona competence on the performance of economics teachers through work motivation was $28 \%$.

Work motivation can strengthen the influence of empowering leadership on lecturer performance.

Work motivation minimizes the influence of empowering leadership on permanent lecturers' performance. The difference is not significant, as evidenced by the effect size value of $0.007 \geq 0.02$ (small), 0.15 (medium), and 0.35 (large), which falls into the category of small influence. The findings of this study contradict the findings of Sundarsi \& Wardiningsih (2012), who found that motivation moderates the effects of leadership on employee performance. As per Fadime \& Kaban (2012) findings, work motivation strengthens the relationship between leadership and employee performance. According to expert analysis and previous studies, work motivation can strengthen the relationship between empowering leadership and lecturer performance. The higher a leader's empowerment and the lecturers' work motivation, the better the lecturers' performance in implementing the Tridharma.

\section{Work motivation can strengthen the influence of lecturer professionalism on lecturer performance.}

Work motivation can strengthen the influence of professionalism on the performance of permanent lecturers significantly, where the value is 0.027 , belongs to the small influence category. The path coefficients value is 0.16 , which means every increase in professionalism moderated by work motivation by 1 unit, which increases the performance of lecturers by 0.16 . The results of this study confirm the opinion of Zee et al. (2018) that a person's performance achievement who is motivated by someone who does not have both internal and external motivation must be different. Since motivation influences a person's reaction and work process, lecturers' competency can be strengthened. Spencer \& Spencer (1993) suggest competence as a person's underlying characteristics related to the effectiveness of individual performance in work or basic characteristics of individuals who have causal relationships or causal references are effective, primary, or superior achievers at work or in certain situations. The results of this study are following the results of research Tone (2018), shows that the role of work motivation as a moderate is proven to strengthen the influence of commitment and competence of lecturers in working under the Tridharma of higher education which consists of education, research and community service.

\section{Self-efficacy can strengthen the influence of empowering leadership on lecturer performance.}

Self-efficacy minimizes the influence of empowering leadership on the performance of permanent lecturers, however, this effect is not significant, as evidenced by the effect size value of 0.010 (R2 value), which falls into the category of small influence. This suggests that when empowering leadership improves, lecturer performance does not substantially increase, even though lecturers' self-efficacy 
improves, but not significantly. The findings of this study contradict those of Dennerlein (2017) and Hao et al. (2017), who found that work variable-role self-efficacy could enhance the influence of empowering leadership on performance.

\section{Locus of control can strengthen the influence of lecturer professionalism on lecturer performance.}

Path Coefficient value $=0.02$ and $P$-value $<0.36<0.05$ with an R2 value from the effect size is 0.003 , falls into the category of small influence. Locus of control can strengthen the professionalism influence on the performance of permanent lecturers in private universities in Jambi and Riau Provinces, but not significantly. The path coefficients value is 0.02 , which means that every increase in professionalism that moderated locus of control by 1 unit will increase the performance of lecturers by 0.02 . It means that the higher the professionalism of the lecturers, the better the performance of the lecturers because the locus of control factor owned by the lecturers is also higher with a 95\% confidence level (error 5\%). Furthermore, Ho rejected, and $\mathrm{Ha}$ accepted. The results of this study are following the research results of Ratnawati (2020) and Gautama \& Dwirandra (2017). Based on expert opinion and previous research, it concluded that in addition to work motivation, locus of control able to strengthen the relationship between professionalism and lecturer performance in implementing the Tridharma.

\section{Conclusion}

The study's findings include that the fit and quality index models have validated their value; with results are as follows: empowering leadership has a positive and significant effect on lecturer performance; professionalism has a positive but not significant effect on lecturer performance; work motivation has a positive and significant effect on lecturer performance; work motivation partially mediates the effect of empowering leadership on lecturer performance; work motivation fully mediates the effect of professionalism on lecturer performance; motivation weakens the effect of empowering leadership on lecturer performance but not significantly; work motivation can significantly strengthen the influence of professionalism on lecturer performance; self-efficacy weakens the effect of empowering leadership on lecturer performance but not significantly; locus of control can strengthen the influence of professionalism on lecturer performance but not significantly. Other findings outside the hypothesis proposed by the authors are empowering leadership which has a positive and significant effect on lecturers' work motivation, and professionalism has a positive and significant effect on the work motivation of permanent lecturers at private high schools in Jambi and Riau provinces.

\section{Limitation}

The following are some of the study's limitations: 1) According to the required number of samples, the number of respondents was only 317 , which does not represent the actual situation; 2) The research focuses solely on the performance of permanent lecturers in universities and excludes nonpermanent lecturers. 3) Because the authors are unable to attend the universities due to the pandemic, the information provided to respondents via questionnaires is collected using Google Forms.

\section{References}

[1] Abeng, T. (2002). Dari Meja Tantri Abeng, Gagasan, Wawasan, Terapan dan Renungan. Jakarta: Pustaka Sinar Harapan.

[2] Ahearne, M., Mathieu, J., \& Rapp, A. (2005). To Empower or Not to Empower Your Sales Force? An Empirical Examination of the Influence of Leadership Empowerment Behavior on Customer Satisfaction and Performance. Journal of Applied Psychology, 90(5), 945-955. doi: 10.1037/0021-9010.90.5.945

[3] Ahmed, I., Khan, M. K., \& Bhatti, G. A. (2017). Linking Empowering Leadership, Psychological Empowerment, Self-Leadership, Creative Involvement and Creativity: A Sequential Mediation Model. Lahore Journal of Business, 5(2), 67-80. doi: 10.35536/ljb.2017.v5.i2.a4

[4] Amundsen, S., \& Martinsen, Ø. L. (2014). Empowering leadership: Construct clarification, conceptualization, and validation of a new scale. The Leadership Quarterly, 25(3), 487-511. doi: 10.1016/j.leaqua.2013.11.009

[5] Andriani, S., Kesumawati, N., \& Kristiawan, M. (2018). The Influence Of The Transformational Leadership And Work Motivation On Teachers Performance Septi. International Journal of Scientific and Technology Research, 7(7), 19-29.

[6] Bagraim, J., \& Werner, A. (2003). Organisational behaviour: $A$ contemporary South African perspective. Van Schaik.

[7] Bandura, A. (1997). Self Efficacy - The Exercise of Control. New York: W.H. Freeman \& Company.

[8] Bangsawan, Sawitri, D., \& Nasir, M. J. A. (2020). Analisis Karakteristik Individu dan Kompetensi Terhadap Kinerja Dimediasi Motivasi Kerja Personil Bidang Umum Dan Keuangan POLTEKAD Malang. Journal Of Economics and Management, 21(2), 63-76.

[9] Basri, T. H., Muda, I., \& Lumbanraja, P. (2019). The Effect of Professionalism , Organizational Culture , Leadership Style Independence Auditors on Auditor Performance with Intelligence Spiritual as a Variable Moderating on Office Public Accountants in Medan. International journal of research and review (IJRR), 6(6), 163-179.

[10] Bass, B. M. (1990). From transactional to transformational leadership: Learning to share the vision. Organizational Dynamics, 18(3), 19-31. doi: 10.1016/0090-2616(90)90061-s

[11] Bastari, A., Eliyana, A., \& Wijayanti, T. W. (2020). Effects of transformational leadership styles on job performance with job motivation as mediation: A study in a state-owned enterprise. Management Science Letters, 2883-2888. doi: 10.5267/j.msl.2020.4.019

[12] Cojocariu, S. (2011). Management Ethics and Motivation in Organizations providing Tourism Services. QUALITY-access to success, 121(3).

[13] Dash, S. S., \& Vohra, N. (2019). The leadership of the school principal. Management Research Review, 42(3), 352-369. doi: 10.1108/mrr-11-2017-0384

[14] Dennerlein, T. (2017). Empowering Leadership and Employees Achievement Motivations: The Role of Self-Efficacy and Goal Orientations in the Empowering Leadership Process. Erasmus Research Institute of Management - ERIM.

[15] Sayoga Diputra, D. G. A. (2018). The Influence of Leadership and Organizational Climate of Employee Performance through Motivation as a Mediation Variable. International Journal of Contemporary Research and Review, 9(08), 20986-20996. doi: 10.15520/ijcrr/2018/9/08/571

[16] Çınar, F., \& Kaban, A. (2012). Conflict Management and Visionary Leadership: An Application in Hospital Organizations. Procedia Social and Behavioral Sciences, 58, 197-206. doi: 10.1016/j.sbspro.2012.09.993

[17] Fitria, H., Mukhtar, M., \& Akbar, M. (2017). THE EFFECT OF ORGANIZATIONAL STRUCTURE AND LEADERSHIP STYLE ON TEACHER PERFORMANCE IN PRIVATE SECONDARY SCHOOL. IJHCM (International Journal of Human Capital Management), 1(02), 101-112. doi: 10.21009/ijhcm.012.12

[18] Fornell, C., \& Larcker, D. F. (1981). Evaluating Structural Equation Models with Unobservable Variables and Measurement Error. Journal of Marketing Research, 18(1), 39-50. doi: $10.1177 / 002224378101800104$

[19] Gachengo, V., \& Wekesa, S. (2017). Influence of motivation on employee performance: a case of national bank of Kenya. International Journal of Business Management and Social 
Research, 3(2), 179-185, doi: 10.18801/ijbmsr.030217.20

[20] Gautama, P. K., \& Dwirandra, A. A. N. B. (2017). Locus of Control Sebagai Pemoderasi Pengaruh Profesionalisme dan Kompleksitas Tugas pada Kinerja Auditor. E-Jurnal AKuntansi Univeristas Udayana, 20(3), 2131-2159.

[21] Griffin, R. W. (2004). Manajemen. Jakarta: Erlangga.

[22] Guterresa, L. F. D. C., Armanu, A., \& Rofiaty, R. (2020). The role of work motivation as a mediator on the influence of educationtraining and leadership style on employee performance. Management Science Letters, 1497-1504. doi: 10.5267/j.msl.2019.12.017

[23] Hamalik, O. (2002). Psikologi Belajar Mengajar. Bandung: Sinar Baru Algasindo.

[24] Hao, P., He, W., \& Long, L.-R. (2017). Why and When Empowering Leadership Has Different Effects on Employee Work Performance: The Pivotal Roles of Passion for Work and Role Breadth SelfEfficacy. Journal of Leadership \& Organizational Studies, 25(1), 85-100. doi: $10.1177 / 1548051817707517$

[25] Hartinah, S., Suharso, P., Umam, R., Syazali, M., Lestari, B. D., Roslina, R., \& Jermsittiparsert, K. (2020). Teacher's performance management: The role of principal's leadership, work environment and motivation in Tegal City, Indonesia. Management Science Letters, 235-246. doi: 10.5267/j.msl.2019.7.038

[26] Hasbullah, R., \& Moeins, A. (2016). The Influnce of Professionalism, Achievement Motivation and Empowerment Against the Work Discipline and Its Implication on Teacher Performance: Empirical Study on High School Teachers in Karawang Regency. International Journal of Business and Commerce, 5(06), 18-36.

[27] Jones, D. L. (2013). Empowering Leadership (1 ed.). Frederiksberg: Ventus Publishing ApS.

[28] Jumriati, Suryadi, \& Sjamsir, H. (2018). The Effects of Supervision, Social Competence, and Professional Competence Toward the Teachers Performance of State of Junior High School. Indonesian Journal of Educational Review, 5(1), 11-16. doi: 10.1017/CBO9781107415324.004

[29] Kreitner, R., \& Kinicki, A. (2014). Perilaku Organisasi (9 ed.). Jakarta: Salemba Empat.

[30] Kusuma, A. H. P., Rina, \& Syam, A. H. (2018). The Main Role of Locus of Control and Professional Ethics on Lecturer's Performance (Indonesian Lecturer Empirical Study). International Review of Management and Marketing, 8(5), 9-17.

[31] Lam, L. W. (2012). Impact of competitiveness on salespeople's commitment and performance. Journal of Business Research, 65(9), 1328-1334. doi: 10.1016/j.jbusres.2011.10.026

[32] Latham, G. (2012). Work Motivation: History, Theory, Research, and Practice. doi: 10.4135/9781506335520

[33] Mathis, R. L., \& Jackson, J. H. (2012). Manajemen Sumber Daya Manusia (1 ed.). Jakarta: Salemba Empat.

[34] Mawardi, A. (2011). Peningkatan Kompetensi Pedagogik Dosen di Jurusan Teknik Sipil Politeknik Negeri Lhokseumawe. Jurnal BISSOTEK, 6(1), 1-13.

[35] McClelland, D. C. (1987). Human Motivation. New York: Cambridge University Press.

[36] Morrow, P. C., \& Goetz, J. F. (1988). Professionalism as a form of work commitment. Journal of Vocational Behavior, 32(1), 92-111. doi: 10.1016/0001-8791(88)90008-5

[37] Nurlaela, Wasaraka, F. M., \& Mokodompit, M. P. (2017). The Influence of Leadership, Work Motivation and Work Environment on Lecturer's Performance at University X. ResearchGate, 250252.

[38] Oprescu, C. M., \& Militaru, E. (2012). The Improvement of Employee Performance by the Implementation of Motivational Strategies. QUALITY-Access to Success, 13(126)

[39] Permanasari, R., Setyaningrum, R. M., \& Sundari, S. (2016). MODEL HUBUNGAN KOMPETENSI, PROFESIONALISME DAN KINERJA DOSEN. JBMP (Jurnal Bisnis, Manajemen Dan Perbankan), 1(2), 157. doi: 10.21070/jbmp.v1i2.270

[40] Pervan, M., Curak, M., \& Pavic Kramaric, T. (2017). The Influence of Industry Characteristics and Dynamic Capabilities on Firms' Profitability. International Journal of Financial Studies, 6(1), 4. doi: $10.3390 /$ ijfs 6010004

[41] PP. (2009). Peraturan Pemerintah Republik Indonesia Nomor 37 Tahun 2009 Tentang Dosen.

[42] Pujiastuti, S., Murwatiningsih, \& Rozi, F. (2017). The Influence of
Professional Competence and Working Environment to The Teachers Performance of The Economic Teachers in Senior High School At Pemalang Regency Through Their Working Motivation. Journal of Economic Education, 6(2), 151-160. doi: 10.15294/jeec.v6i2.19301

[43] Putra, I. G. B. W., \& Ariyanto, D. (2012). Pengaruh Independensi, Profesionalisme, Struktur Audit, dan Role Stress Terhadap Kinerja Auditor BPK RI Perwakilan Provinsi Bali. E-Jurnal Akuntansi, 1(1), $1-18$

[44] Ramadika, A. P., Nasir, A., \& Wiguna, M. (2014). Pengaruh Role Stress, Gender, Struktur Audit dan Profesionalisme terhadap Kinerja Auditor BPK-RI Perwakilan Provinsi Riau. JOM Fekon, 1(2), 1-15.

[45] Ratnawati, V. (2020). Factors affecting tax auditors' performance: the moderating role of locus of control. Problems and Perspectives in Management, 18(2), 36-45. doi: 10.21511/ppm.18(2).2020.04

[46] Robbins, S. P. (2008). Organizational Behaviour (Tenth Edit). Jakarta: Salemba Empat.

[47] Sandrin, É., Gillet, N., Fernet, C., \& Leloup, M. (2019). Effects of motivation and workload on firefighters ' perceived health , stress, and performance. Stress and Health, 1-10. doi: 10.1002/smi.2873

[48] Sappe, S., Rante, Y., Tuhumena, R., \& Bharanti, B. E. (2016). Effect of Leadership on Employee's Performance Mediated by Cultural Organization, Work Commitment and Motivation. Journal of Economics and Behavioral Studies, 8(2), 101-107.

[49] Sarboini, Rizal, S., Surya, J., \& Yusuf, Z. (2018). The Effect of Leadership, Compensation And Competency on Employee Performance of Banda Aceh Public Health Office. The International Journal of Social Sciences, 6(2), 215-234.

[50] Sardjana, E., Sudarmo, S., \& Suharto, D. G. (2019). The Effect of Remuneration, Work Discipline, Motivation on Performance. International Journal of Multicultural and Multireligious Understanding, 5(6), 136. doi: 10.18415/ijmmu.v5i6.529

[51] Shah, N. P., Levin, D. Z., \& Cross, R. (2018). Secondhand social capital: Boundary spanning, secondhand closure, and individual performance. Social Networks, 52, 18-27. doi: 10.1016/j.socnet.2017.04.005

[52] Sholihin, M., \& Ratmono, D. (2021). Analisis SEM-PLS dengan WarpPLS 7.0. Yogyakarta: CV. Andi Offset.

[53] Spencer, M. L., \& Spencer, M. S. (1993). Competence at Work, Models For Superior Performance. Canada: John Wiley \& Sons, Inc.

[54] Suliyanto. (2018). Metode Penelitian Bisnis untuk Skripsi, Tesis, \& Disertasi. Yogyakarta: CV. Andi Offset.

[55] Sundarsi, K., \& Wardiningsih, S. S. (2012). Pengaruh Kepemimpinan dan Komunikasi Terhadap Kinerja dengan Motivasi sebagai Variabel Moderasi. Jurnal Manajemen Sumberdaya Manusia, 6(1), 11-21. doi: 10.1017/CBO9781107415324.004

[56] Tone, K. (2018). Examining the Moderating Effect of Work Motivation on the Lecturer Performance: A Contribution to Organizational Commitment and Competence. Research in Business and Management, 5(2), 1. doi: 10.5296/rbm.v5i2.12773

[57] Tone, K., Gani, M. U., Nujum, S., \& Latief, B. (2015). The Impact of Antecedent Variable on Lecturer' Performance as Mediated by Work Motivation, 4(10), 54-62.

[58] Trisnaningsih, S., Suparwati, \& Hendra, F. H. (2012). The Factors that Influence to Lecturers Performance with Motivation as an Intervening Variable. The Fourth UB International Consortium on Accounting, 1-25.

[59] Trivena, T., \& Harisno, H. (2014). THE EFFECT OF LECTURER'S PROFESSIONALISM AND STUDENT'S STUDY INTEREST AND MOTIVATION ON ACADEMIC ACHIEVEMENT OF BACHELOR DEGREE STUDENT IN ONLINE LEARNING IN BINUS UNIVERSITY. CommIT (Communication and Information Technology) Journal, 8(2), 55. doi: 10.21512/commit.v8i2.596

[60] Tung, H., \& Chang, Y. (2011). Effects of empowering leadership on performance in management team. Journal of Chinese Human Resources Management, 2(1), 43-60. doi: $10.1108 / 20408001111148720$

[61] Undang-Undang. (2005). Undang-Undang Republik Indonesia Nomor 14 Tahun 2005 Tentang Guru dan Dosen.

[62] Undang-Undang. (2012). Undang-Undang Republik Indonesia Nomor 12 Tahun 2012 Tentang Pendidikan Tinggi.

[63] Vecchio, R. P., Justin, J. E., \& Pearce, C. L. (2010). Empowering leadership: An examination of mediating mechanisms within a 


\section{GENERAL MANAGEMENT}

hierarchical structure. The Leadership Quarterly, 21(3), 530-542. doi: 10.1016/j.leaqua.2010.03.014

[64] Vroom, V. H. (2006). Manajemen Sumber Daya Manusia. Alih Bahasa: Ngalim Purwanto. Jakarta: PT. Mediasoft.

[65] Wibisono, C., Nurhatisyah, N., \& Gustiawan, F. (2018). Work motivation and leadership on the performance of employees as predictors of organizational culture in broadcasting commission of FIAU islands province, Indonesia. Management Science Letters, 247-258. doi: 10.5267/j.msl.2018.4.026
[66] Zee, K. S., Cavallo, J. V., Flores, A. J., Bolger, N., \& Higgins, E. T. (2018). Motivation moderates the effects of social support visibility. Journal of Personality and Social Psychology, 114(5), 735-765. doi: $10.1037 /$ pspi0000119

[67] Zhang, P., \& Gheibi, S. (2015). The Impact of Empowering Leadership on Work Performance and Work Family Conflict: the Role of Gender. European Scientific Journal, 11(11), 367-379. doi: 10.19044/esj.2015.v11n11p\%p 